ODNOS KOEFICIJENTA KAPITALNIH ULAGANJA, RAČUNOVODSTVENE I INTERNE STOPE PRINOSA

\author{
Mehmed Meta, prof. dr \\ Internacionalni Univerzitet u Novom Pazaru \\ Novi Pazar, Srbija \\ m.meta@uninp.edu.rs
}

\begin{abstract}
Apstrakt
Teorijska istraživanja u oblasti finansijskog menadžmenta rezultirala su brojnim metodama koje se uspešno mogu koristiti pri oceni efikasnosti investicionih zahvata. Ekonomisti koji se bave ovim problemima, metode ocene efikasnosti ulaganja najčešće tretiraju u vidu složenih matematičkih modela, što ih korisnicima bez posebnog matematičkog obrazovanja čini isuviše komplikovanim.

Pristupi metodama ocene ekonomske efikasnosti investicionih zahvata koji se baziraju na matematičkim modelima, dugo vremena su uticali da se u praksi preferiraju oni metodi koji se zasnivaju na tradicionalnom (računovodstvenom) poimanju rentabilnosti. I u našoj privrednoj i bankarskoj praksi nisu u dovoljnoj meri prihvatani metodi koji se pri oceni ekonomske efikasnosti oslanjaju na prilivu i odlivu novca i uvažavanju koncepta njegove vremenske vrednosti.

Cilj ovoga rada je da se kod pojedinih specifičnih investicionih zahvata ukaže na vezu koja postoji između računovodstvene stope prinosa i koeficijenta kapitalnih ulaganja, kao tipično statičkih metoda ocene, sa jedne strane i interne stope prinosa kao najznačajnijeg diskontnog merila efikasnosti ulaganja, sa druge strane.
\end{abstract}

Ključne reči: vreme povraćaja, računovodstvena stopa prinosa, koeficijent kapitalnih ulaganja, interna stopa prinosa, novčani tok.

\title{
RELATIONSHIP OF THE CAPITAL INVESTMENT COEFFICIENT, ACCOUNTING AND INTERNAL RATE OF RETURN
}

\begin{abstract}
The theoretical research in the field of financial management resulted in a number of methods that can be successfully used in assessing the effectiveness of investments. Economists, who deal with these problems, usually treat methods of assessment of investment efficiency as a complex mathematical model, making them too complicated for beneficiaries without a special mathematics education.

Methods of assessment of the economic efficiency of investments that are based on mathematical models have for a long time caused that methods based on traditional (accounting) understanding of profitability were preferred in practice. The same is true for our economic and banking practices where methods of the assessment of economic efficiency that rely on the inflow and outflow of money and respect the concept of time value are not enough adopted.

The aim of this paper is to show that in certain specific investment projects a relationship exists between the accounting rate of return and the coefficient of capital investment, as
\end{abstract}


representatives of static investment method, on the one hand and the internal rate of return as the most significant discount criterion of efficiency of investment, on the other hand.

Keywords: time of return, accounting rate of return, the ratio of capital investment, internal rate of return, cash flow.

JEL codes: E22

\section{UVODNA RAZMATRANJA}

Ocena ekonomske efikasnosti investicionih ulaganja čini najbitniju komponentu investicionih programa i biznis planova. Kao rezultat ove analize dobija se određeni broj pokazatelja o ekonomskoj opravdanosti planiranih investicionih zahvata. Dobijeni rezultati služe kao osnova za donošenje odluke, mada donosilac investicione odluke u procesu odlučivanja, po pravilu uzima u obzir i druge momente. Cilj izrade investicionog programa je da se donosiocu investicione odluke pruže objektivne i relevantne informacije o svim važnijim ekonomskim aspektima ulaganja. Kvalitet dela investicionog programa koji se odnosi na ocenu efikasnosti investicionih zahvata primarno je uslovljen nivoom stručnosti svih onih analiza i projekcija koje služe kao njegova informaciona podloga, kompetentnošću ljudi koji je obavljaju i metodama ocene na kojima će se zasnivati.

Smisao finansijske ocene investicionih zahvata je da se na osnovu projektovanih efekata i ulaganja u ekonomskom veku projekta izvrši obračun pokazatelja njegove efikasnosti. Osnovni problem, koji se pri proračunu pokazatelja efikasnosti javlja, sastoji se u neusaglašenosti potrebne i raspoložive informacione podloge. Ovaj problem se može prevazići samo dobrim poznavanjem metodologije ocene efikasnosti investicionih projekata i teorijsko-praktičnog aspekta računovodstva i finansiranja od strane lica koja vrše analizu.

Ocena efikasnosti investicionih zahvata se može vršiti primenom različitih metoda. Svi oni imaju manju ili veću upotrebnu vrednost i svojih dobrih ili loših strana. U ovom radu želimo posebno potencirati ulogu koeficijenta kapitalnih ulaganja, kao statičkog merila efikasnosti investicionih zahvata, koji se računski dobija iz recipročne vrednosti vremena povraćaja kapitala. Značaj ovog koeficijenata se ogleda u činjenici što on pod određenim uslovima aproksimira računovodstvenoj stopi prinosa i internoj stopi prinosa. Za ovakvu aproksimaciju investicioni zahvat se treba karakterisati sledećim:

- da ima ujednačen godišnji iznos efekata tokom čitavog ekonomskog veka;

- da mu je rezidualna vrednost na kraju ekonomskog veka jednaka nuli;

- $\quad$ da su godišnji iznosi bruto akumulacije u svim godinama ekonomskog veka međusobno jednaki; i

- da mu je vek eksploatacije znatno duži od vremena povraćaja investiranog kapitala (4, str. 322-326.).

\section{UVODNA RAZMATRANJA}

Metod vremena povraćaja (Pay-Back Method) je jedan od najznačajnijih nediskontnih merila ocene efikasnosti investicionih zahvata. Kao što zajmodavce 
interesuje za koji će period novac dat u obliku kredita biti u formi anuiteta vraćen, a prodavce određene robe zanima vremenski period za koji će sredstva blokirana pri nabavci biti deblokirana prodajom, tako i racionalne investitore interesuje za koji će vreme ulaganja u određeni zahvat biti deblokirana, odnosno reakumulirana.

Da bi se izračunalo vreme povraćaja $(s)$, potrebno je staviti u odnos iznos koji se planira investirati $(I)$ sa iznosom efekata, odnosno godišnjeg neto priliva koji se očekuju ostvariti $(E)$ :

$$
s=\frac{I}{E}
$$

Vreme povraćaja dobijeno primenom gornjeg obrasca ima svoju upotrebnu vrednost samo u slučaju ako se investicioni zahvat karakteriše jednokratnim ulaganjem i godišnjim međusobno jednakim (anuitetskim) efektima.

Odluka o prihvatanju investicione ideje primenom ovog metoda pretpostavlja definisanje jedinstvenog investicionog kriterijuma, kao prihvatljivog vremena povraćaja. To praktično znači da će nezavisni projekti biti prihvaćeni ako je period povraćaja kraći od utvrđenog prihvatljivog vremena. Kod konkurentnih projekata, koji zadovoljavaju investicioni kriterijum, biće prihvaćen onaj čiji je period povraćaja kraći. Međutim, zasnivanje investicionih odluka samo na korišćenju ovog metoda u većini slučajeva nije prihvatljivo, jer je vreme povraćaja determinisano ne samo veličinom efekata koji će u periodu eksploatacije investicionog objekta biti ostvareni i visinom inicijalnih kapitalnih ulaganja, već i prirodom i karakterom samog investicionog zahvata.

I pored očite prednosti koja se ogleda u jednostavnom utvrđivanju ovog perioda, metod vremena povraćaja je bremenit i mnoštvom nedostataka, od kojih su posebno značajni sledeći:

- ne vodi računa o preferenciji vremena, kao komponenti kapitalnih ulaganja i efekata, jer ne koristi diskontnu stopu;

- ne uzima u obzir efekte posle vremena povraćaja i njihov uticaj na efikasnost investicionih ulaganja; i

- ne ukazuje na stvarnu rentabilnost ulaganja (7, str. 92).

U teoriji i praksi investicionog menadžmenta pri oceni investicionih varijanti se često koristi i koeficijent koji se dobija iz recipročne vrednosti vremena povraćaja. Recipročnu vrednost vremena povraćaja, odnosno količnik efekata ulaganja i iznosa investicionih troškova, neki autori nazivaju koeficijentom kapitalnih ulaganja. Njegova vrednost inverzno varira sa promenom vremena povraćaja. Koeficijent kapitalnih ulaganja $(d)$ se izražava odnosom veličine jednogodišnjih efekata i iznosa ukupnih kapitalnih ulaganja, odnosno:

$$
d=\frac{E}{I}
$$

Ovako dobijeni koeficijent pokazuje godišnji iznos neto priliva na jedinicu angažovanog kapitala. Njegov značaj se posebno ogleda u činjenici što on pod određenim uslovima aproksimira računovodstvenoj i internoj stopi prinosa. 
Na osnovu obrazaca (1) i (2) zaključujemo da vreme povraćaja investiranog kapitala i koeficijent kapitalnih ulaganja zavise samo od iznosa inicijalnih ulaganja i visine godišnjih efekata, a ne i od dužine ekonomskog veka projekta. Stoga se ova dva indikatora efikasnosti investicionih zahvata geometrijski prikazuju u obliku pravih linija koje su paralelne sa apcisnom osom.

\section{RAČUNOVODSTVENA STOPA PRINOSA KAO KRITERIJUM EFIKASNOSTI}

Računovodstvena stopa prinosa, pored vremena povraćaja i njegove recipročne vrednosti (koeficijenta kapitalnih ulaganja), predstavlja značajno statičko merilo efikasnosti investicionih zahvata. Kao veličina koja pokazuje iznos profita na jedinicu angažovanog kapitala, rentabilnost ulaganja primenom ovog metoda se dobija iz odnosa planiranog profita i projektovanih ulaganja. Razumljivo je da ishod dobijenog rezultata zavisi od toga šta se podrazumeva pod pojmom profita i pod pojmom kapitalnih ulaganja. Jako širok dijapazon mišljenja u ekonomskoj teoriji postoji pri pojmovnom određenju ove dve kategorije.

U brojiocu obrasca za izračunavanje računovodstvene stope prinosa se najčešće uzima (7, str. 79-80):

- iznos akumulacije u prvoj godini eksploatacije projekta,

- iznos akumulacije u čitavom ekonomskom veku trajanja investicije,

- iznos prosečne godišnje akumulacije,

- zbir akumulacije i kamate na pozajmljeni kapital u prvoj godini eksploatacije,

- zbir akumulacije i kamate u čitavom ekonomskom veku,

- zbir prosečne godišnje akumulacije i prosečne godišnje kamate na pozajmljeni kapital.

Računovodstvena stopa prinosa zavisi i od poimanja kategorije kapitalnih ulaganja, kao veličine koja se nalazi u imeniocu obrasca za njeno izračunavanje. Kapitalna ulaganja se kvantitativno najčešće izražavaju:

- visinom ukupnih ulaganja u osnovna i trajna obrtna sredstva do momenta aktiviranja projekta;

- visinom ukupnih ulaganja u osnovna sredstva;

- prosečnom visinom angažovanog kapitala u osnovna i trajna obrtna sredstva tokom ekonomskog veka projekta;

- prosečnom veličinom angažovanog kapitala u osnovna sredstva tokom ekonomskog veka.

Ovi načini izražavanja profita i kapitalnih ulaganja za potrebe izračunavanja računovodstvene stope prinosa predstavljaju najčešće prisutne oblike u ekonomskoj teoriji i praksi, ali ne i jedine. Tako npr. M.H. Abdelsamad navodi 24 načina iskazivanja brojioca i 36 načina iskazivanja imenioca, čime ukazuje na mogućnost izražavanja ove stope na 864 različita načina ( 1. str. 44-66). 
U praksi se najčešce koristi prosečna računovidstvena stopa prinosa $(r)$, koja se dobija iz dnosa prosečne bruto akumulacije ( $\bar{h}(\bar{k})$ i visine prosečno angažovanog kapitala (ij, odnosno:

$$
r=\frac{\overline{l k}}{\bar{I}}
$$

gde je,

$$
\begin{gathered}
\bar{i} \bar{k}=\frac{A k_{1}+A k_{2}+A k_{3}+\cdots+A k_{(n-2)}+A k_{(n-1)}+A k_{n}}{n} \\
\bar{I}=\frac{I_{0}+I_{1}+I_{2}+I_{3}+\cdots+I_{(n-2)}+I_{(n-1)}+I_{n}}{n+1}
\end{gathered}
$$

Upotrebljeni simboli označavaju:

$A k_{1}, A k_{2}, A k_{3}, \ldots, A k_{(n-2)}, A k_{(n-1)}, A k_{n}-$ godišnju bruto akumulaciju (zbir godišnje neto akumulacije i kamate) u prvoj. drugoj, trećoj,...i $n$-toj godini ekonomskog veka projekta;

$I_{n}$ - blokirani kapital na kraju ekonomskog veka projekta (rezidualna vrednost projekta);

$I_{0}+I_{1}+I_{2}+I_{3}+\cdots+I_{(n-2)}+I_{(n-1)}$ - zbir ukupnog blokiranog kapitala na kraju nulte, prve, druge, treće, $\ldots,(\mathrm{n}-2)$ i $(n-1)$ godine;

$n-$ ekonomski vek projekta.

Zbir prosečne godišnje neto akumulacije i prosečne godišnje kamate predstavlja prosečan prinos na ukupni kapital (sopstveni i pozajmljeni) i naziva se prosečnom bruto akumulacijom. Prosečno angažovana sredstva se dobijaju sabiranjem blokirane vrednosti osnovnih i trajnih obrtnih sredstava na kraju svake godine eksploatacije investicionog objekta iznosom u trenutku aktiviranja kapaciteta i deljenjem dobijene veličine brojem koji je za 1 veći od vremena eksploatacije. Dugoročno blokirana sredstva na kraju svake godine u odnosu na kraj prethodne godine su manja za iznos troškova amortizacije. Ako se vek trajanja svih osnovnih sredstava poklapa sa periodom eksploatacije, a projektom se ne planira ulaganje u trajna obrtna sredstva, iznos prosečno angažovanog kapitala je jednak polovini

\begin{tabular}{|c|c|c|c|c|}
\hline Godina & Godišnji amortizovani iznos & $\begin{array}{c}\text { Neamortizovani } \\
\text { iznos } \\
\end{array}$ & Efekti & $\begin{array}{c}\text { Bruto } \\
\text { akumulacija }\end{array}$ \\
\hline 1 & 2 & 3 & 4 & 5 \\
\hline 0 & - & 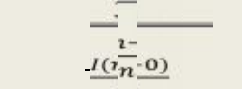 & - & - \\
\hline 1 & - & $\frac{1-1}{1\left(n_{n}-1\right)}$ & - & - \\
\hline 2 & $1 / n$ & $\underline{t(n-\bar{n} \cdot 2)}$ & $E$ & $\begin{array}{l}E-I / n \\
E-I / n\end{array}$ \\
\hline
\end{tabular}
njegove inicijalne vrednosti.

Tabela 1. Dinamika amortizacije, amortizovanog iznosa, efekata i bruto akumulacije 


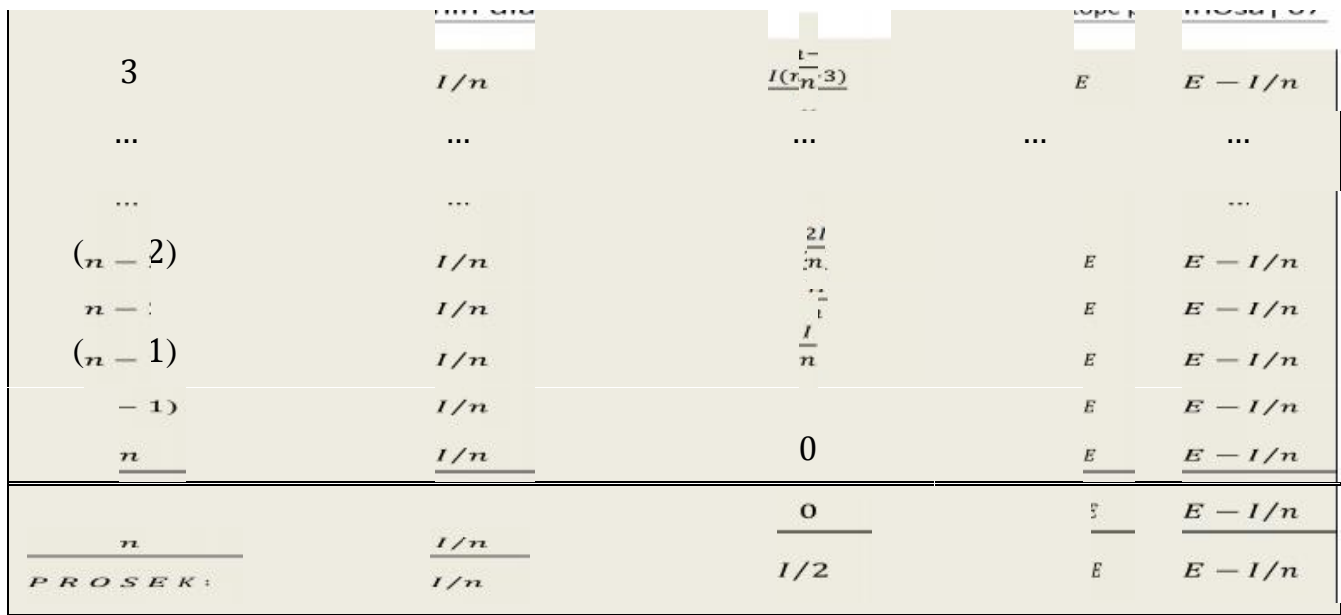

Kolona 2 u gornjoj tabeli sadrži podatke o godišnjoj amortizaciji. Uvažavajući pretpostavku o primeni ravnomernog modela amortizacije i jednakosti amortizacionog perioda i ekonomskog veka projekta, godišnji iznosi troškova amortizacije moraju biti međusobno jednaki, a njihov zbir je jednak iznosu ukupnih inicijalnih ulaganja koja se planiraju izvršiti u nultoj godini. Kolona 4 prikazuje dinamiku ukupnog neto novčanog priliva u ekonomskom veku (zbir godišnje amortizacije i bruto akumulacije), odnosno godišnje efekte ulaganja, Zadnja kolona prikazuje iznose bruto akumulacije (zbir godišnje neto akumulacije i godišnje kamate na pozajmljena sredstva koja će se koristiti pri finansiranju investicionog zahvata), kao komponente neto novčanog priliva sredstava u ekonomskom veku projekta. Pošto su obe komponente ukupnog neto novčanog toka (troškovi amortizacije i bruto akumulacija) konstantne veličine, to se godišnja bruto akumulacija može računski izraziti wi 'kau razlika ukupnih godišnjih efekata $(E)$ i godišnje amortizacije $(I / n)$, odnosn

$$
\overline{A k}=E-\frac{I}{n}
$$

Prosečan angažovani kapital $(\bar{I})$ se dobija kao količnik zbira ukupnog neamortizovanog iznosa na kraju svake godine i broja koji je za jedan veći od ekonomskog veka projekta:

$$
\bar{I}=\frac{\frac{I(n-0)}{n}+\frac{I(n-1)}{n}+\frac{I(n-2)}{n}+\cdots+\frac{2 I}{n}+\frac{I}{n}+0}{n+1}
$$

odnosno:

$$
\bar{I}=\frac{\frac{I}{n}[(n-0)+(n-1)+(n-2)+\cdots+2+1+0]}{n+1}
$$


gde izraz u srednjoj zagradi predstavlja aritmetički niz čiji je svaki naredni u odnosu na prethodni član manji za 1 . Po pravilima aritmetičke progresije, on se može predstaviti kao zbir prvog i zadnjeg člana u nizu pomnoženog brojem koji je jednak polovini broja članova u nizu. Pošto je prvi član izraza $(n-0)$, zadnji član nula, a broj članova $(n+1)$, obrazac koji prikazuje prosečan angažovani kapital će glasiti:

$$
\bar{I}=\frac{I\left(\frac{n+1}{2}\right)}{n+1}=\frac{I}{2}
$$

Pošto je bruto akumulacija ista u svim godinama ekonomskog veka projekta računovodstvena stopa prinosa kod projekata sa ovakvim karakteristikama se može izraziti pomoću obrasca:

$$
r=\frac{E-\frac{I}{n}}{\frac{1}{2} I}
$$

Računovodstvena stopa prinosa je jednaka količniku godišnje bruto akumulacije i polovine iznosa inicijalno investiranog kapitala.

\section{ODNOS RAČUNOVODSTVENE STOPE PRINOSA I KOEFICIJENTA KAPITALNIH ULAGANJA}

Kod projekata sa jednokratnim ulaganjima u nultoj godini i višegodišnjim međusobno jednakim efektima, pod određenim pretpostavkama mogu biti uspostavljeni odnosi između računovodstvene stope prinosa i perioda povraćaja, odnosno njegove recipročne vrednosti (koeficijenta kapitalnih ulaganja), kao bazičnih nediskontnih metoda ocene efikasnosti investicija. Naime, ako se investicioni zahvat, sem jednokratnim ulaganjem i jednakošću efekata $u$ ekonomskom veku, karakteriše:

- Konstantnim iznosom bruto akumulacije tokom čitavog ekonomskog veka $\left(A k_{1}=A k_{2}=A k_{3}=\cdots=A k_{n}=A k\right)$;

- Primenom ravnomernog modela vremenske amortizacije $\left(A m_{1}=A m_{2}=\right.$ $\left.A m_{3}=\cdots=A m_{n}=A m\right) \mathrm{i}$

- Odsustvom rezidualne vrednosti $\left(A m_{1}+A m_{2}+A m_{3}+\cdots+A m_{n}=I\right)$

računovodstvena stopa prinosa može biti dobra aproksimacija vremena povraćaja investiranog kapitala, odnosno njegove recipročne vrednosti (4, str. 332-334).

Pri poznatom vremenu povraćaja investiranog kapitala i godišnjim efektima, iznos inicijalnog kapitala iznosi:

$$
I=E \cdot S
$$


zamenom u inicijalni obrazac za izračunavanje računovodstvene stope prinosa dobijamo:

$$
r=\frac{2\left(E-\frac{E \cdot s}{n}\right)}{E \cdot s}
$$

čijim sređivanjem dobijamo obrazac:

$$
r=\frac{2}{s}-\frac{2}{n}
$$

Pošto je $s=1 / d$ gornji obrazac se može prikazati i u obliku:

$$
r=2 d-\frac{2}{n}
$$

Analizom gornjih izraza (5) i (6) zaključujemo sledeće:

- računovodstvena stopa prinosa je jednaka nuli ako je $n=1 / d$, odnosno ako je period povraćaja jednak ekonomskom veku projekta;

- računovodstvena stopa prinosa će biti jednaka koeficijentu kapitalnih ulaganja $(r=d)$, ako je $n=2 / d$, odnosno ako je ekonomski vek projekta dva puta duži od perioda povraćaja;

- sa povećanjem ekonomskog veka računovodstvena stopa prinosa degresivno raste i pri beskonačno velikoj vrednosti $n$ ona aproksimira iznos koji je dvostruko veći od koeficijenta kapitalnih ulaganja (u zadnjem obrascu ako $n \rightarrow \infty$ umanjilac $2 / n \rightarrow 0$, pa je $r=2 d$ ).

\section{ELASTIČNOST RAČUNOVODSTVENE STOPE PRINOSA UVODNA RAZMATRANJA}

Uvažavajući postavke od kojih smo u modelu pošli, vidimo da računovodstvena stopa prinosa zavisi od ekonomskog veka projekta. Stoga je kvantitativno moguće izmeriti stepen njene elastičnosti (osetljivosti, senzitiviteta, fleksibilnosti) na promenu ovog parametra. Za merenje stepena osetljivosti računovodstvene stope prinosa na promenu ekonomskog veka projekta koristi se koeficijent njene elastičnosti. On se dobija iz odnosa relativne (procentualne) promene $u$ računovodstvenoj stopi prinosa i relativne (procentualne) promene u dužini ekonomskog veka. Ako apsolutnu promenu u ekonomskom veku projekta označimo sa $\Delta n$, njoj odgovarajuću promenu u računovodstvenoj stopi prinosa sa $\Delta r$, računovodstvenu stopu prinosa pre promene ekonomskog veka projekta sa $r$, a bazni iznos dužine ekonomskog veka sa $n$, koeficijent elastičnosti se može prikazati izrazom: 


$$
{ }_{n} E_{r}=\frac{\frac{\Delta r}{r} 100}{\frac{\Delta n}{n} 100}
$$

Ako je algebarski oblik krive računovodstvene stope prinosa poznat, korektni rezultati za koeficijent njene elastičnosti se dobijaju ako elastičnost određujemı za određenu infinitezimalnu promenu u ekonomskom veku. To praktično znači utvrđivanje elastičnosti u jednoj tački. U tom slučaju promena u dužini ekonomskog veka postoji, ali je ona toliko mala, da praktično teži nuli ( $\Delta n \rightarrow 0)$. Pri izračunavanju koeficijenta elastičnosti računovodstvene stope prinosa u jednoj tački se polazi od gornjeg izraza, koji se može napisati i u obliku:

$$
{ }_{n} E_{r}=\frac{n \Delta r}{r \Delta n}
$$

u kojoj $\Delta r / \Delta n$ označava nagib krive računovodstvene stope prinosa. Između nagiba ove krive i koeficijenta elastičnosti postoji sustinska razlika, jer je elastičnost sem nagibom određena i odnosom dužine ekonomskog veka projekta i računovodstvene stope prinosa pri datom ekonomskom veku.

Pri vrlo maloj promeni u ekonomskom veku $(\Delta n \rightarrow 0)$, gornji izraz dobija oblik:

$$
{ }_{n} E_{r}=\frac{n}{r} \lim _{\Delta n \rightarrow 0} \frac{\Delta r}{\Delta n}=\frac{n}{r} \frac{d r}{d n}
$$

u kome je $d r / d n$ izvod funkcije računovodstvene stope prinosa po argumentu $n$.

Pri funkciji računovodstvene stope prinosa:

$$
r=2 d-\frac{2}{n}
$$

njena elastičnost pri bilo kojoj dužini ekonomskog veka iznosi:

odnosno:

$$
{ }_{n} E_{r}=\frac{n}{\left(\frac{2}{s}-\frac{2}{n}\right)}\left(\frac{2}{s}-\frac{2}{n}\right)^{\prime}
$$

$$
{ }_{n} E_{r}=\frac{s}{(n-s)}
$$

Pošto je vreme povraćaja investiranog kapitala iznosi $s=1 / d$, to se obrazac za izračunavanje elastičnosti računovodstvene stope prinosa može napisati i u obliku:

$$
{ }_{n} E_{r}=\frac{1}{(n d-1)}
$$


Analizom izraza (7) i (8) zaključujemo sledeće:

$$
\begin{aligned}
& >{ }_{n} E_{r}=\infty \text { za } n=1 / d \text {, odnosno za } n=s \\
& >1<{ }_{n} E_{r}<\infty \text { za } 1 / d<n<2 / d \text {, odnosno za } s<n<2 s \\
& >{ }_{n} E_{r}=1 \text { za } n=2 / d, \text { odnosno za } n=2 s \\
& >0<{ }_{n} E_{r}<1 \text { za } 2 / d<n<\infty \text {, odnosno za } 2 s<n<\infty \\
& >{ }_{n} E_{r}=0 \text { za } n=\infty .
\end{aligned}
$$

\section{INTERNA STOPA PRINOSA}

Metod interne stope prinosa, pored metoda neto sadašnje vrednosti, metoda anuiteta, indeksa profitabilnosti, prosečne stope prinosa i diskontovanog vremena povraćaja, spada u diskontna merila ocene efikasnosti projekata. Za razliku od metoda neto sadašnje vrednosti, kod ovog metoda problem se ne postavlja u formi pitanja: kolika će biti neto sadašnja vrednost pri datoj diskontnoj stopi, nego koliko treba da iznosi diskontna stopa da bi neto sadašnja vrednost bila nula?

Kod projekta sa jednogodišnjim ulaganjima u iznosu od $I$ i godišnjim efektima $E_{1}, E_{2}, E_{3} \ldots, E_{(n-1)}$ i $E_{n}$ do interne stope prinosa se dolazi korišćenjem izraza:

$$
\frac{E_{1}}{(1+\hat{p})^{1}}+\frac{E_{2}}{(1+\hat{p})^{2}}+\frac{E_{3}}{(1+\hat{p})^{3}}+\cdots+\frac{E_{(n-1)}}{(1+\hat{p})^{(n-1)}}+\frac{E_{n}}{(1+\hat{p})^{n}}=I
$$

u kojoj kao jedina nepoznata figurira ṕ, koja označava internu stopu prinosa.

Ako su efekti u svim godinama ekonomskog veka međusobno jednaki, odnosno ako važi relacija:

$$
E_{1}=E_{2}=E_{3}=\cdots=E_{(n-1)}=E_{n}=E
$$

jednačina (9) dobija oblik:

$$
I=\frac{E}{(1+\hat{p})^{1}}+\frac{E}{(1+\hat{p})^{2}}+\frac{E}{(1+\hat{p})^{3}}+\cdots+\frac{E}{(1+\hat{p})^{(n-1)}}+\frac{E}{(1+\hat{p})^{n}}
$$

odnosno:

$$
E\left[\frac{(1+\dot{\mathrm{p}})^{n}-1}{(1+\dot{\mathrm{p}})^{n} \dot{\mathrm{p}}}\right]=I
$$

čijim rešavanjem po $I / E$ dobijamo

$$
\left[\frac{(1+\dot{\mathrm{p}})^{n}-1}{(1+\dot{\mathrm{p}})^{n} \dot{\mathrm{p}}}\right]=\frac{I}{E}
$$


Tabela 2. Obračun neto sadašnje vrednosti kod projekata sa jednakim efektima

\begin{tabular}{|c|c|c|c|c|}
\hline Godina & Ulaganja & Efekti & $\begin{array}{c}\text { Sadašnja vrednost } \\
\text { ulaganja }\end{array}$ & Sadašnja vrednost efekata \\
\hline 1 & 2 & 3 & 5 & 4 \\
\hline 0 & $\frac{2}{1}$ & - & $\frac{\frac{21 a g a l}{5} \frac{1 a}{-}-}{1 /(1+p) 0}$ & - \\
\hline & & - & & - \\
\hline 1 & & E & & $E /(1+P)^{1}$ \\
\hline 2 & & $\begin{array}{l}E \\
E\end{array}$ & & $\begin{array}{l}E /(1-p)^{1} \\
E /\left(1+{ }_{p}\right)^{2}\end{array}$ \\
\hline & & E & & $E / C 1 P^{1-}$ \\
\hline 3 & & E & & $E /(1+p)^{3}$ \\
\hline$\cdots$ & & $\cdots$ & & $\cdots$ \\
\hline$\ldots$ & & ... & & 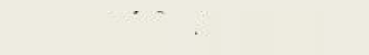 \\
\hline$(n-2)$ & & E & & $E /\left(1+{ }_{p}\right)^{(n-2)}$ \\
\hline$n-$ : & & E & & $E /(1+\hat{p}$ \\
\hline$(n-1)$ & & $E$ & & $E /\left(1+{ }_{p}\right)^{(n-1)}$ \\
\hline -1) & & E & & $\left(1+1 \mathrm{Cn}^{-}\right.$ \\
\hline$\underline{n}$ & & $\underline{E}$ & & $E /(1+\underline{p})^{n}$ \\
\hline \multicolumn{2}{|c|}{ Vrednosti u nultom periodu : } & - & $I$ & 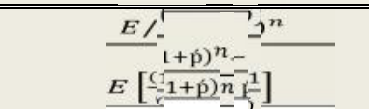 \\
\hline
\end{tabular}

Pošto je $I / E=s$, zadnji izraz se može napisati i kao:

$$
\left[\frac{(1+\dot{p})^{n}-1}{(1+\hat{p})^{n} \dot{p}}\right]=s
$$

Vreme povraćaja investiranog kapitala kod projekata sa ovakvim karakteristikama mora biti jednako faktoru $I V$ finansijske tablice za broj godina $n$ i diskontnu stopu koja je jednaka internoj stopi prinosa .

Pošto leva strana izraza (11) označava vrednost faktora $I V$ finansijske tablice, odnosno recipročnu vrednost anuitetnog faktora, a desna vreme povraćaja investiranog kapitala, to se inverzijom datog izraza dobija:

$$
\left[\frac{(1+\dot{\mathrm{p}})^{n} \mathrm{p}}{(1+\mathrm{p})^{n}-1}\right]=\frac{E}{I}
$$

gde leva strana označava vrednost faktora $V$ finansijske tablice, a desna recipročnu vrednost vremena povraćaja, odnosno koeficijent efikasnosti investicije $(E / I=d)$.

$$
\left[\frac{(1+\dot{p})^{n} \dot{p}^{\prime}}{(1+\hat{\mathrm{p}})^{n}-1}\right]=d
$$


Faktor $V$ finansijske tablice, odnosno anuitetni faktor kod investicionih zahvata sa ovakvim specifičnostima, kada ekonomski vek iznosi $n$ godina, a diskontna stopa je jednaka internoj stopi prinosa, mora biti jednak recipročnoj vrednosti vremena povraćaja.

\section{ODNOS INTERNE STOPE PRINOSA I KOEFICIJENTA KAPITALNIH ULAGANJA}

Vreme povraćaja investiranog kapitala, odnosno koeficijent kapitalnih ulaganja, pod određenim uslovima može aproksimirati internoj stopi prinosa. Ako uvažimo pretpostavku o anuitetnom toku efekata u ekonomskom veku projekta $\left(E_{1}=E_{2}=\right.$ $\left.E_{3}=\cdots=E_{(n-2)}=E_{(n-1)}=E_{n}=E\right)$, interna stopa prinosa se dobija izraza (10), u kojoj $\hat{p}$ označava internu stopu prinosa, odnosno kamatnu stopu pri kojoj se sadašnja vrednost svih efekata izjednačava sa iznosom inicijalnih kapitalnih ulaganja.

Množenjem izraza (10) sa $(1+\hat{p})$ dobijamo:

$I(1+\hat{p})=E+\frac{E}{(1+\hat{p})^{1}}+\frac{E}{(1+\hat{p})^{2}}+\cdots+\frac{E}{(1+\hat{p})^{(n-2)}}+\frac{E}{(1+\hat{p})^{(n-1)}}$

Oduzimanjem izraza (10) od (13) imamo:

čijim rešavanjem po $\hat{p}$ dobijamo

$$
I \hat{p}=E-\frac{E}{(1+\hat{p})^{n}}
$$

$$
\hat{p}=\frac{E}{I}\left[1-\frac{1}{(1+\hat{p})^{n}}\right]
$$

Pošto je $E / I=d$ gornji izraz se može prikazati u obliku:

$$
\hat{p}=d-\frac{d}{(1+\hat{p})^{n}}
$$

Analizom izraza (14) zaključu emo sledeće (7 str.101):

- Interna stopa prinosa će biti jednaka koeficijentu kapitalnih ulaganja $(\hat{p}=d)$ ako projekat sa anuitetnim godišnjim efektima ima neograničen vek trajanja $(n=\infty)$;

- Pri datom koeficijentu kapitalnih ulaganja i ograničenom ekonomskom veku projekta, interna stopa prinosa je uvek manja od vrednosti koeficijenta kapitalnih ulaganja $(\hat{p}<d)$;

- Ako se pri datom koeficijentu kapitalnih ulaganja ekonomski vek projekta povećava razlika između koeficijenta kapitalnih ulaganja i interne stope prinosa se smanjuje i obratno; 
- Ako je ekonomski vek projekta jednak vremenu povraćaja investiranog kapitala interna stopa prinosa je jednaka nuli.

Iako koeficijent kapitalnih ulaganja pod određenim uslovima aproksimira internoj stopi prinosa, on ne može biti korišćen kao osnovni i jedini kriterijum pri oceni rentabilnosti, pogotovu ne kod projekata koji nemaju anuitetni novčani tok i kod kojih razlika između ekonomskog veka i perioda povraćaja nije dovoljno velika. No, njegova uloga kao dopunskog kriterijuma može biti od izuzetne važnosti pri alternativnom odlučivanju o projektima koji imaju približno istu rentabilnost merenu nekim od metoda koji se baziraju na cash flow analizi ili računovodstvenom stopom prinosa. U takvim situacijama, prioritet treba dati projektima sa većim koeficijentom kapitalnih ulaganja, odnosno kraćim periodom povraćaja, jer takav izbor obezbeđuje veću likvidnost, odnosno veći godišnji procenat pokrića ukupno investiranih sredstava.

\section{ZAKLJUČAK}

Ekonomska i finansijska dimenzija merenja efikasnosti investicionih zahvata podrazumeva definisanje odgovarajućih parametara koji će služiti kao kriterijum za njihovu ocenu. U komparaciji dobijenih rezultata sa definisanim kriterijumima se donosi sud o prihvatanju realizacije određene investicione ideje ili rangiranje investicionih varijanti koje su međusobno konkurentne. Sama ocena ekonomske efikasnosti može se bazirati na primeni nekih od konvencionalnih merila efikasnosti (metod vremena povraćaja, koeficijent kapitalnih ulaganja, metod računovodstvene stope prinosa i sl.) ili onih metoda koji uvažavaju koncept vremenske vrednosti novca (metod neto sadašnje vrednosti, metod interne stope prinosa, metod indeksa profitabilnosti i sl.). Naša analiza je pokazala da pod određenim uslovima koeficijent kapitalnih ulaganja može biti zadovoljavajuća aproksimacija za internu i računovodstvenu stopu prinosa. Naime, ako se investicioni zahvat karakteriše jednokratnim ulaganjem u nultom periodu i višegodišnjim anuitetskim efektima, odsustvom rezidualne komponente, ravnomernim sistemom obračuna amortizacije, jednakošću ekonomskog veka projekta i amortizacionog perioda, kao i ekonomskim vekom koji je znatno duži od vremena povraćaja, interna stopa prinosa se približava koeficijentu kapitalnih ulaganja, a računovodstvena stopa prinosa je duplo veća od njih. Ove konstatacije ukazuju i na to da investicioni zahvati sa ovakvim karakteristikama moraju imati pozitivnu neto sadašnju vrednost i pozitivan iznos indeksa profitabilnosti ako je definisani investicioni kriterijum, odnosno diskontna stopa manja u odnosu na dobijeni koeficijent kapitalnih ulaganja.

Iako se definisani odnosi između dvaju konvencionalnih metoda ocene efikasnosti ulaganja (koeficijenta kapitalnih ulaganja i računovodstvene stope prinosa) i interne stope prinosa kao najznačajnijeg diskontnog metoda, baziraju na brojnim pretpostavkama što se karakteristika ulaganja i efekata tiče, njihova praktična primena se ne može ignorisati. Mnogi realni projekti, posebno oni iz oblasti infrastrukture (izgradnja putne mreže, izgradnja brana, vodovodne i elektro mreže i sl), u manjoj ili većoj meri imaju te karakteristike. 


\section{BIBLIOGRAFIJA}

1. Abdelsamad, M.H., A Guide to Capital Expenditure Analysis, Amacom, New York, 1973.

2. James C. Van Horne, John M. Wachowich. Osnove finansijskog menadžmenta, Zagreb : MATE, 2002.

3. Jovanović, P., Upravljanje investicijama. Beograd, Grafoslog, 2001.

4. Krasulja D., Ivanišević M., Poslovne finansije, Ekonomski fakultet Beograd, Beograd, 2000.

5. Kljusev, N., Teorija i ekonomika investicija u preduzeću, Ekonomski fakultet, Skoplje, 1965.

6. Milisavljevć, M., savremeni strategijski menadžment, Megatrend,

7. Meta, M., Upravljanje investicijama, Novi Pazar, IUNP, 2015.

8. Meta, M., Senzitivitet investicioni ulaganja sa anuitetskih efektima, Socioeconomica - The Scientific Journal for Theory and Practice of Socioeconomic Development, 2014, 3(6): 239-252.

9. Meta, M., Korišćenje koeficijenata elastičnocti u investicionoj analizi, časopis Pravno-ekonomski pogledi, 2014/Broj 1/ Godina 5, str. 51-64

10. Orsag, S., Budžetiranje kapitala-Procjena investicijskih projekata, Masmedija, Zagreb, 2002.

11. Terborgh, G., The Required Return from Investment Project Mashinery and Allied Producst, Institute, Research Study No 4,1963

12. Đuričin, D., Lončar, D., Menadžment pomoću projekata, Beograd, Ekonomski fakultet, 2007.

\section{RESUME}

The aim of this paper is to show that in certain specific investment projects a relationship exists between the accounting rate of return and the coefficient of capital investment, as representatives of static investment method, on the one hand and the internal rate of return as the most significant discount criterion of efficiency of investment, on the other hand.

The economic and financial dimensions for measuring efficiency of investments involves defining the appropriate settings, which will serve as the criteria for their evaluation. In comparing the results obtained with defined criteria judgments are made about the acceptance of the realization of certain investment ideas or ranking of investment variants that are competitive with each other. The assessment of economic efficiency can be based on the application of some of the conventional criteria of efficiency (time of return method, the coefficient of capital investment, accounting rate of return method, etc.) or those methods that take into account the concept of the time value of money (net present value, internal rate of return method, methods of profitability indexes, etc.). Our analysis has shown that under certain conditions the coefficient of capital investment can be a satisfactory approximation of internal and accounting rate of return. Namely, if the investment procedure is characterized by one-off investment in zero-period and long annuity effects, absence of residual components, uniform system of calculation of depreciation, the equality of economic life of the project and the amortization 
period, as well as economic life, which is considerably longer than the time of return, internal rate of return is approaching the coefficient of capital investment, and the accounting rate of return is twice the size of them. These findings indicate that the investment activities with these characteristics must have a positive net present value and profitability index if the defined investment criteria, and the discount rate is lower than the coefficient of obtained capital investment.

Although defined relations between the two conventional methods of assessment of investment efficiency (ratio of capital investment and accounting rate of return) and internal rate of return as the most significant discount method are based on numerous assumptions with regard to the characteristic of investments and its effects, their practical application cannot be ignored. Many real projects, especially those in the field of infrastructure (construction of road network, construction of dams, plumbing and electrical networks, etc.), in a greater or lesser extent have these characteristics. 